\title{
Evaluation of students' knowledge as a contribution to dengue control programs
}

\author{
Avaliação do conhecimento dos estudantes \\ como contribuição ao programa de controle da dengue
}

Juliana Maria Trindade Bezerra ${ }^{1}$

Joelma Soares-da-Silva ${ }^{1}$

Sebastiana Silva Ibiapina ${ }^{1}$

Wanderli Pedro Tadei ${ }^{2}$

Valéria Cristina Soares Pinheiro ${ }^{1}$

${ }^{1}$ Laboratório de

Entomologia Médica,

Curso de Ciências

Biológicas, Centro de

Estudos Superiores de

Caxias, Universidade

Estadual do Maranhão.

Praça Duque de Caxias s/n,

Morro do Alecrim.

65600-000 Caxias MA.

juliana.bezerra@cpqrr.fiocruz.br

${ }^{2}$ Instituto Nacional de

Pesquisas da Amazônia

(INPA)

\begin{abstract}
This study describes a survey $(n=700)$ carried out in 14 elementary schools in the municipality of Caxias, State of Maranhão, Brazil. The survey was conducted between July and December 2007 in schools from seven neighborhoods on the outskirts of the western part of the municipality, where for the past three years high densities of immature Aedes aegypti mosquitoes have been recorded. The students' knowledge of dengue, its vector, and disease prevention was evaluated by targeted questionnaires. The students with the most comprehensive knowledge were found in schools in the Trizidela neighborhood, which has better social and urban conditions than the other neighborhoods. Moreover, educational campaigns are necessary to reinforce behavioral changes of the population, because the existence of breeding sites in the areas examined was mentioned, especially in the Tamarineiro neighborhood. The survey can be used to assist with new educational activities of local teams working with dengue control.
\end{abstract}

Key words Knowledge, Students, Practical Activities, Dengue
Resumo Trata-se de um inquérito amostral (700 entrevistas) realizado em 14 Escolas Públicas da Rede Municipal de Ensino na cidade de Caxias, Estado do Maranhão. O inquérito foi realizado entre julho e dezembro de 2007, em escolas localizadas em sete bairros periféricos da zona oeste, os quais apresentaram registros de alta densidade de imaturos de Aedes aegypti nos últimos três anos. Avaliou-se por meio da aplicação de questionário fechado, o conhecimento dos escolares sobre o dengue, seu vetor e prevenção. Os resultados mostraram que as escolas do bairro Trizidela, com melhores condições sociais e urbanas em relação aos demais bairros periféricos, apresentaram estudantes com conhecimentos mais adequados. Contudo, as campanhas educativas são necessárias como medidas para fortalecer as mudanças de comportamento da população, pois foi mencionada a existência de criadouros nas áreas examinadas, com maior prevalência dos recipientes de armazenamento no bairro Tamarineiro. A pesquisa pode servir como subsídio para orientar novas ações educativas das equipes locais de controle do dengue.

Palavras-chave Conhecimento, Estudantes, Práticas, Dengue 


\section{Introduction}

Dengue is currently the most important insectborne arbovirus with respect to morbidity and mortality. In many countries, chemical control has proved inadequate to prevent infestation by the mosquito vector. Many measures, including sanitation and trash removal; epidemiological, entomological, and virological vigilance; health education; and community participation are essential to decisively prevent outbreaks ${ }^{1,2}$.

The lack of a national sanitation policy, as well as the lack of efficient control of $A$. aegypti are aggravating factors for the high incidence of dengue $^{3,4}$. Thus, when a community recognizes its role in applying preventive and control measures against the dengue vector, it can become a strong ally in controlling the disease. However, nearly all educational campaigns focused on popular participation are limited to orienting the community to avoid accumulating water containers and to take care in discarding household waste. These campaigns provide little or no information on the biological characteristics of the vector or measures to prevent mosquito proliferation. Moreover, the educational materials, i.e. posters and leaflets, contain information that is difficult to understand. Information on dengue is transmitted to the population in an uncoordinated and essentially theoretical manner ${ }^{5}$.

Dengue is currently reported from almost the entire territory of Brazil, with the single exception of the state of Santa Catarina where no autochthonous cases have been reported. During the 20 first weeks of 2009, 332,083 suspected cases of dengue were reported in the country ${ }^{6}$. In the state of Maranhão, the number of cases rose sharply in 2007, with 14,616 reports and 163 cases of dengue hemorrhagic fever (DHF), which resulted in 13 deaths $^{7}$. From January to November 2008, 5,920 suspect cases were reported in the state, five of them DHF, with three deaths ${ }^{8}$. During the first 10 weeks of 2009, 386 cases were reported $^{9}$. In the municipality of Caxias, 905 cases of dengue were reported from 2000 to 2006. From January to October 2008, 169 cases of dengue were reported, with one death ${ }^{10}$. The risk of dengue outbreaks in Caxias is increasing. Although it is the third-largest city in Maranhão, the population of Caxias faces severe sanitation problems, especially those related to water supply. The population is also poorly informed about dengue, and has low socioeconomic levels.

Because of the importance of community participation for the prevention of dengue, the objective of this survey was to evaluate some aspects of knowledge about dengue, its vector, and preventive measures among the student population in Caxias.

\section{Material and Methods}

\section{Study area}

The municipality of Caxias is located in the eastern part of the State of Maranhão (451'32"S; $\left.43^{\circ} 21^{\prime} 2^{\prime \prime} \mathrm{W}\right)$, with an area of $5,313.2 \mathrm{~km}^{2}$ and a mean altitude of $67 \mathrm{~m}$ above sea level. The climate is typically tropical, with a mean annual temperature of $28.39^{\circ} \mathrm{C}$; annual precipitation averages $1,454.6 \mathrm{~mm}$, with a drier period from July to December ${ }^{11}$.

The population of Caxias in 2002 was 144,387, with a density of 25 inhab $/ \mathrm{km}^{2}$ and an annual growth rate of $1.06 \%$ (12). For the organization of the epidemiological survey, we selected the seven neighborhoods in the western portion of the municipality with the highest indices of immature Aedes aegypti and dengue records: Caldeirões, Campo de Belém, Pirajá, Ponte, Salobro, Tamarineiro, and Trizidela. This information was provided by the Program for Endemic Disease Control of Caxias, Maranhão (Programa de Controle de Endemias de Caxias, Maranhão).

The population of the neighborhoods in this part of the municipality has a low socioeconomic level. Most of the houses are constructed of mud-brick and the streets are unpaved. Sanitation conditions are inadequate, mainly regarding the public water supply, which is quite irregular. Open sewers allow mosquito proliferation and emit foul odors. In most of these neighborhoods, trash accumulates on vacant land and in the yards of residences.

\section{Data collection}

Data were collected using a questionnaire, which was previously used in nine other neighborhoods of the municipality in order to confirm the accuracy of the method and the quality of the answers obtained. Each residence was considered a sample unit, and each responsible person who was at least 18 years of age was interviewed. If a selected house was closed, it was replaced by the house next door. Five percent of the surveyed residences were supervised, in order to monitor the information obtained. After the required corrections and adaptations for use for 
students were made, the definitive questionnaire was composed and used in the schools.

The questionnaire consisted of ten questions on dengue, information on Aedes aegypti, measures to prevent their proliferation, and the means to obtain information about the disease. Each question had several choices of answers and only one correct answer, as follows: "How is dengue spread? By the bite of an infected female mosquito Aedes aegypti," "What are the main symptoms of dengue? Body aches and fever," "What is the mosquito that transmits dengue? Aedes aegypti," "What does the dengue mosquito look like? Dark with white spots on the body," "Where does the dengue mosquito breed? In water," "How many life stages does Aedes aegypti have? Four." Some questions had no single correct answer: "What is the most important thing that you do in your home to prevent Aedes aegypti from breeding?", "What kinds of containers in your home can accumulate water?", "How did you learn about dengue?" and "What source of information gives you the most knowledge about dengue?"

The urban area of Caxias contains 251 elementary schools ${ }^{12}$. Two schools from each neighborhood were selected, for a total of 14 schools surveyed. From each school, 50 students in the $4^{\text {th }}$ and $6^{\text {th }}$ grades were selected, for a total of 700 students interviewed.

The research project was approved by the Research Ethics Committee of Presidente Dutra University Hospital, administered by the Federal University of Maranhão (Comitê de Ética em Pesquisa do Hospital Universitário Presidente Dutra,
Universidade Federal do Maranhão), protocol number 33104-1277/2007. All the guardians of the students signed the free and informed consent form.

\section{Data analyses}

Contingency tables were used to evaluate the association between the categorical variables. In the table, each dependent variable (responses regarding knowledge of dengue, the vector, and preventive measures) was cross-tabulated with the independent variable (neighborhoods), and the Pearson's Chi-square test $\left(\chi^{2}\right)$ was performed to verify the significance of the relationship between the variables. Statistical analyses were performed using the software Systat, version $10.2^{13}$. A probability level of 0.05 was used as the level of significance in all tests.

\section{Results}

Of the 700 students surveyed, 52\% were males, not a statistically significant proportion $\left(\chi^{2}=\right.$ $6.891 ; \mathrm{df}=6 ; \mathrm{p}>0.001)$. However, there was a significant difference among the neighborhoods in relation to the students' ages, who were mostly 11 to 15 years old $\left(58.4 \% ; \chi^{2}=64.874 ; \mathrm{df}=6 ; \mathrm{p}<\right.$ $0.001)$.

Table 1 presents the students' knowledge about dengue. The mean numbers of correct answers varied significantly among the neighborhoods. One of the questions - "How is dengue transmit-

Table 1. Number of students' answers about the dengue according to the neighborhood where schools are located - Caxias, Maranhão, Brazil, 2007.

\begin{tabular}{|c|c|c|c|c|}
\hline \multirow[b]{2}{*}{ Neighborhood } & \multicolumn{2}{|c|}{ Dengue transmission } & \multicolumn{2}{|c|}{ Main symptoms } \\
\hline & Correct Answer & Incorrect Answers & Correct Answers & Incorrect Answers \\
\hline Caldeirões & 50 & $50^{* *}$ & 56 & $44^{* *}$ \\
\hline Campo de Belém & 61 & 39 & 93 & 7 \\
\hline Pirajá & 81 & 19 & 96 & 4 \\
\hline Ponte & 59 & 41 & 97 & 3 \\
\hline Salobro & 65 & 35 & 84 & 16 \\
\hline Tamarineiro & 66 & 34 & 94 & 6 \\
\hline Trizidela & $87^{*}$ & 13 & $98^{*}$ & 2 \\
\hline \multirow[t]{2}{*}{ Total } & $469(67.1 \%)$ & $231(32.9 \%)$ & $618(88.4 \%)$ & $82(11.6 \%)$ \\
\hline & \multicolumn{2}{|c|}{$\begin{array}{c}\chi^{2}=44.776 \\
\text { df }=6 \\
p<0.001\end{array}$} & \multicolumn{2}{|c|}{$\begin{array}{c}\chi^{2}=130.093 \\
\text { df }=6 \\
p<0.001\end{array}$} \\
\hline
\end{tabular}

Highest frequency of correct answers. ${ }^{* *}$ Highest frequency of incorrect answers. 
ted?" was properly answered by $67.1 \%$ of the students $\left(\chi^{2}=44.776 ; \mathrm{df}=6 ; \mathrm{p}<0.001\right)$. Regarding the symptoms, $88.4 \%$ of them mentioned body pain and fever $\left(\chi^{2}=130.093\right.$; $\left.\mathrm{df}=6 ; \mathrm{p}<0.001\right)$. The neighborhood of Trizidela had the highest percentage of correct answers in both subjects, $87 \%$ and $98 \%$ respectively. The neighborhood of Caldeirões had the lowest percentages, with 50\% and 56\% correct answers, respectively.

There were also significant differences in the students' knowledge about $A$. aegypti. The question "What is the dengue mosquito transmitter?" was properly answered by $84.3 \%$ of the students $\left(\chi^{2}=33.630 ; \mathrm{df}=6 ; \mathrm{p}<0.001\right) .80 .5 \%$ of the students knew that this mosquito species has a dark body covered with white spots $\left(\chi^{2}=83.585\right.$; $\mathrm{df}=6 ; \mathrm{p}<0.001)$. The question "Where does the dengue mosquito breed?" was properly answered by $82.7 \%$ of the students $\left(\chi^{2}=42.368\right.$; $\mathrm{df}=6$; $\mathrm{p}<$ 0.001 ). About mosquito life stages, $61.4 \%$ answered the question correctly, i.e., the mosquito has four life stages $\left(\chi^{2}=66.906 ; \mathrm{df}=6 ; \mathrm{p}<0.001\right)$. Again, the students in Trizidela were best informed about the characteristics of the dengue vector, whereas the students in Caldeirões and Tamarineiro gave the fewest correct responses (Table 2).

With respect to the attitudes of students about preventing the proliferation of the vector at home, $79.7 \%(\chi 2=55.621, \mathrm{df}=6, \mathrm{p}<0.001)$ said that we should not allow water to accumulate in disposable or storage containers. Students in the Trizidela neighborhood again gave the most correct responses about measures to take at home to prevent dengue.

When asked about the type of containers present at the students' homes, those for water storage (i.e., water tanks and pails) were the most cited, by $58.8 \%$ of the students, a significant result $\left(\chi^{2}=24.316 ; \mathrm{df}=6 ; \mathrm{p}<0.001\right)$. The students who most reported the presence of such containers lived in Tamarineiro, with 61 responses.

The number of correct questions regarding the required measures to prevent dengue at home, and the reason to prevent water collecting in containers, was 96 and 99, respectively. With respect to the information sources, television was cited as the main source of knowledge by $48.2 \%$ of the students. However, health visitors were considered the source that provided the best explanatory information, with a mean significantly higher than television and other information sources $74.4 \%\left(\chi^{2}=47.085 ; \mathrm{df}=6\right.$; $\left.\mathrm{p}<0.001\right)$. The majority of the students from Trizidela pointed out the work of health visitors as the main information source $(88 \%)$.

\section{Discussion}

The results of this study showed that the students surveyed have some knowledge about preventive measures against dengue and the vector A. aegyp$t i$ Similar findings were also observed in surveys by Chiaravalloti $\mathrm{Neto}^{14}$, Donalisio et al. ${ }^{15}$, and

Table 2. Number of students' answers about the dengue mosquito according to the neighborhood where schools are located - Caxias, Maranhão, Brazil, 2007.

\begin{tabular}{|c|c|c|c|c|c|c|c|c|}
\hline \multirow[b]{2}{*}{ Neighborhood } & \multicolumn{2}{|c|}{$\begin{array}{l}\text { Mosquito } \\
\text { transmitter }\end{array}$} & \multicolumn{2}{|c|}{ Characteristics } & \multicolumn{2}{|c|}{$\begin{array}{c}\text { Mosquito } \\
\text { breeding site }\end{array}$} & \multicolumn{2}{|c|}{ Life stages } \\
\hline & $\begin{array}{l}\text { Correct } \\
\text { Answer }\end{array}$ & $\begin{array}{l}\text { Incorrect } \\
\text { Answers }\end{array}$ & $\begin{array}{l}\text { Correct } \\
\text { Answers }\end{array}$ & $\begin{array}{l}\text { Incorrect } \\
\text { Answers }\end{array}$ & $\begin{array}{l}\text { Correct } \\
\text { Answer }\end{array}$ & $\begin{array}{l}\text { Incorrect } \\
\text { Answers }\end{array}$ & $\begin{array}{l}\text { Correct } \\
\text { Answers }\end{array}$ & $\begin{array}{l}\text { Incorrect } \\
\text { Answers }\end{array}$ \\
\hline Caldeirões & 68 & $32^{* *}$ & 53 & $47^{* *}$ & 61 & $39^{* *}$ & 41 & 59 \\
\hline Campo de Belém & 84 & 16 & 85 & 15 & 82 & 18 & 64 & 36 \\
\hline Pirajá & 89 & 11 & 87 & 13 & 85 & 15 & 58 & 42 \\
\hline Ponte & 86 & 14 & 90 & 10 & 85 & 15 & 71 & 29 \\
\hline Salobro & 90 & 10 & 87 & 13 & 86 & 14 & 76 & 24 \\
\hline Tamarineiro & 79 & 21 & 67 & 33 & 86 & 14 & 39 & $61^{* *}$ \\
\hline Trizidela & $94^{*}$ & 6 & $94^{*}$ & 6 & $93^{*}$ & 7 & $80^{*}$ & 20 \\
\hline \multirow[t]{2}{*}{ Total } & $\begin{array}{c}590 \\
(84.3 \%)\end{array}$ & $\begin{array}{c}110 \\
(15.7 \%)\end{array}$ & $\begin{array}{c}563 \\
(80.5 \%)\end{array}$ & $\begin{array}{c}137 \\
(19.5 \%)\end{array}$ & $\begin{array}{c}578 \\
(82.7 \%)\end{array}$ & $\begin{array}{c}122 \\
(17.3 \%)\end{array}$ & $\begin{array}{c}429 \\
(61.4 \%)\end{array}$ & $\begin{array}{c}271 \\
(38.6 \%)\end{array}$ \\
\hline & \multicolumn{2}{|c|}{$\begin{array}{c}\chi^{2}=33.630 \\
\mathrm{df}=6 \\
\mathrm{p}<0.001\end{array}$} & \multicolumn{2}{|c|}{$\begin{array}{c}\chi^{2}=83.585 \\
\text { df }=6 \\
p<0.001\end{array}$} & \multicolumn{2}{|c|}{$\begin{array}{c}\chi^{2}=42.368 \\
\text { df }=6 \\
p<0.001\end{array}$} & \multicolumn{2}{|c|}{$\begin{array}{c}\chi^{2}=66.906 \\
d f=6 \\
p<0.001\end{array}$} \\
\hline
\end{tabular}

Highest frequency of correct answers. ${ }^{* *}$ Highest frequency of incorrect answers. 
Pérez-Guerra et al. ${ }^{16}$. These results are likely related to the many preventive campaigns carried out through media sources, especially television. This information is learned mainly by children and teenagers, who spend much of their time watching television. Children easily assimilate the information received from campaigns, since they are in the stage of cognitive development. They are also able to become involved in actions to prevent or control the dengue vector within their homes. The findings of Brassolatti and Andrade ${ }^{17}$ show that the good level of children's knowledge about the dengue may translate into daily measures that contribute to the reduction in the number of mosquito breeding sites.

Dengue prevention activities such as educational campaigns in schools are an important tool to make the student community aware of the severity of this disease and the care that must be taken at home to prevent the disease. In a study in the municipality of Botucatu, Madeira et al. ${ }^{18}$ verified that students who had the opportunity to watch explanations about dengue, its vector, and related preventive measures, were more able to recognize $A$. aegypti life stages and which measures are considered the most viable to prevent the occurrence of the mosquito. It is worth noting that these results extended to the entire household. The students who had contact with this kind of information had half as many mosquitobreeding sites in their homes, compared to children who had no access to this information.

With respect to the different neighborhoods, children in Trizidela had the highest percentages of accurate responses about the disease and its vector. This may be explained by the better socioeconomic conditions, since the majority of the houses are made of mud-brick, the streets are paved, and the education level is higher compared to other neighborhoods. For instance the neighborhood of Caldeirões had the lowest rate of correct answers, and is the neighborhood where the infrastructure (unpaved streets, houses of mud and lath construction, and gardens with mosquito breeding sites) and sanitation conditions are poorer. These characteristics tend to increase the number of dengue cases in this neighborhood. This community customarily collects water for household consumption, due to failures of the water supply, and the accumulation of trash on vacant land is another aggravating factor affecting the dengue occurrence ${ }^{19}$.

The influence of social inequalities on population health has been discussed in many studies. Despite not finding a linear relationship between adverse living conditions and the occurrence of dengue, the spatial patterns found by Machado et al. ${ }^{20}$ indicate a higher probability of dengue in areas with substandard living conditions and those located close to roads. Other authors, such as Mondini and Chiaravalloti Neto ${ }^{21}$, have found similar results. In a study of socio-economic conditions and dengue transmission, these authors also found a lack of relationship between these two variables, showing that more studies on this issue are needed. This pattern may also depend on the particular socio-economic conditions of each municipality.

Regarding the information sources about dengue, although television was not the most cited means of acquiring information, it is an source for dissemination of educational campaigns to the population. Other, similar studies have shown that television has a strong impact on the dissemination of information about dengue ${ }^{15}$. In the present study, health visitors were cited as the best way to provide information about dengue to the population, showing the importance of the work of these professionals and the need to improve their skills in answering questions, because their visits are generally limited to the inspection of breeding sites ${ }^{19}$.

To create new forms of language in educational activities, fostering greater involvement of the population in the elimination of breeding sites and an effective change in household habits are not easy tasks. They require the creativity of responsible professionals, as well as flexible control programs. Alternatives such as the inclusion in science classes of modules about the study of endemic diseases of a region can also be planned, as in the study conducted by Schweigmann et al. ${ }^{22}$ in Argentina. It is important to emphasize that educational activities have long-term results, are subject to some constraints, and need to be integrated with government activities, mainly in relation to the improvement of basic services, such as adequate residences and a reliable water supply. These issues have been a challenge for dengue prevention in Brazil and worldwide.

The information obtained in this study may support improved efforts to control dengue at the local level, because it shows that there is a considerable degree of theoretical knowledge about the disease among the population. However, it is observed that the practices adopted are still incipient and limited, which highlights the need for changes in formulating anti-dengue campaigns to aim at greater community involvement.

Considering the existing socioeconomic inequalities in Brazil, it is essential that health education, for example information campaigns 
about disease prevention, reach different social and age groups in order to promote equal knowledge and community participation in preventive practices. This has been a challenge for the prevention of dengue in Brazil as well as worldwide.

\section{Collaborators}

JMT Bezerra and VCS Pinheiro were responsible for the design, implementation, analysis, and drafting of the final article. J Soares-da-Silva and SS Ibiapina participated in the execution of the study. WP Tadei was responsible for the analysis and final draft.

\section{Acknowledgements}

We thank the Secretaria Municipal de Educação de Caxias for allowing us to conduct this survey in the schools; and all the directors, professors, students and their guardians for collaborating in this study. We are also thankful to the researchers Ph.D. Miguel Petrere Junior and M. Sc. Henrique Corrêa Giacomini (Universidade Estadual Paulista - UNESP) for helping with the statistical analysis. This research was supported by grants from the Ministério da Educação e Cultura, through the Secretaria de Educação Superior / Programa de Apoio à Extensão Universitária MEC-SESu/PROEXT and CTPetro/Petrobras.

\section{References}

1. Kourí G. El dengue, un problema creciente de salud en las Américas. Rev Panam Salud Publica 2006; 19(3):143-145.

2. Reis IC, Honório NA, Codeço CT, Magalhães MAFM, Lourenço-de-Oliveira R, Barcellos C. Relevance of differentiating between residential and non-residential premises for surveillance and control of Aedes aegypti in Rio de Janeiro, Brazil. Acta Tropica 2010; 114(1):37-43.

3. Medronho RA. Dengue e o ambiente urbano. Rev Bras Epidemiol 2006; 9(2):159-161.

4. Padmanabha $\mathrm{H}$, Soto $\mathrm{E}$, Mosquera M, Lord CC, Lounibos LP. Ecological Links Between Water Storage Behaviors and Aedes aegypti Production: Implications for Dengue Vector Control in Variable Climates. Eco Health 2010; 7(1):78-90.

5. Valla VV. Sobre a participação popular: Uma questão de perspectiva. Cad Saude Publica 1998; 14(Supl. 2):7-18.

6. Brasil. Ministério da Saúde (MS). Secretaria de Vigilância em Saúde. Dengue no Brasil: Informe Eletrônico Epidemiológico 14/2009 Monitoramento CGPNCD. Brasília: Ministério da Saúde (MS); 2009.

7. Brasil. Ministério da Saúde (MS). Fundação Nacional de Saúde. Boletim Eletrônico Epidemiológico. Situação da Dengue no Brasil - 2007. Brasília: Ministério da Saúde (MS); 2007.

8. Brasil. Ministério da Saúde (MS). Secretaria de Vigilância em Saúde. Informe Epidemiológico Eletrônico da Dengue. Janeiro a Novembro de 2008. Brasília: Ministério da Saúde (MS); 2008.

9. Brasil. Ministério da Saúde (MS). Fundação Nacional de Saúde. Informe Eletrônico Epidemiológico da Dengue - Casos de dengue caem 28,6\% no Brasil. Brasília: Ministério da Saúde (MS); 2009.

10. Maranhão. Secretaria Municipal de Saúde de Caxias. Sistema de Informação de Agravos de Notificação. Casos de dengue notificados em Caxias até outubro de 2008. Caxias: Secretaria Municipal de Saúde; 2008.

11. Maranhão. Gerência de Planejamento e Desenvolvimento Econômico. Atlas do Maranhão. São Luís: Governo do Estado do Maranhão; 2002.

12. Instituto Brasileiro de Geografia e Estatística (IBGE). Anuário estatístico do Brasil. Rio de Janeiro: Instituto Brasileiro de Geografia e Estatística; 2002.

13. Systat version 10.2 [computer program]. SPSS, Chicago; 2000 . 
14. Chiaravalloti Neto F. Conhecimentos da população sobre dengue, seus vetores e medidas de controle em São José do Rio Preto, São Paulo. Cad Saude Publica 1997; 13(3):447-453.

15. Donalísio MR, Alves JCP, Visockas A. Inquérito sobre conhecimentos e atitudes da população sobre a transmissão do dengue - região de Campinas, São Paulo, Brasil - 1998. Rev Soc Bras Med Trop 2001; 34(2):197-201.

16. Pérez-Guerra CL, Zielinski-Gutierrez E, VargasTorres D, Clark GG. Community beliefs and practices about dengue in Puerto Rico. Rev Panam Salud Publica 2009; 25(3):218-226.

17. Brassolatti RC, Andrade CFS. Avaliação de uma intervenção educativa na prevenção da dengue. Ciência e Saúde Coletiva 2002; 7(2):243-251.

18. Madeira NG, Macharelli CA, Pedras JF, Delfino MCN. Education in primary school as a strategy to control dengue. Rev Soc Bras Med Trop 2002; 35(3):221-226.

19. Bezerra JMT, Silva BBS, Brito ZM, Pinheiro VCS. Participação popular nas campanhas de combate ao dengue no município de Caxias, Maranhão. Rev Inovação 2007; 5:37-38.

20. Machado JP, Oliveira RM, Souza-Santos R. Análise espacial da ocorrência de dengue e condições de vida na cidade de Nova Iguaçu, Estado do Rio de Janeiro, Brasil. Cad Saude Publica 2009; 25(5):10251034.

21. Mondini A, Chiaravalloti Neto F. Variáveis socioeconômicas e a transmissão de dengue. Rev Saúde Pública 2007; 41(6):923-930.

22. Schweigmann, N, Rizzotti A, Castiglia G, Gribaudo F, Marcos E, Burroni N, Freire G, D'Onofrio V, Oberlander S, Schillaci H, Gómez S, Maldonado S, Serrano C. Información, conocimiento y percepción sobre el riesgo de contraer el dengue en Argentina: dos experiencias de intervención para generar estrategias locales de control. Cad Saude Publica 2009; 25(1): 5137-5148.

Artigo apresentado em 02/08/2009

Aprovado em 11/01/2009

Versão final apresentada em 13/01/2009 
